\title{
CRITICAL DOSE OF NITROGEN AND PHOSPHORUS FOR THE ENHANCED GROWTH, YIELD, AND QUALITY COMPONENTS IN MUSTARD (Sinapsis arvensis L.) IN A SEMI ARID ENVIRONMENT
}

\author{
Firat SEFAOGLU ${ }^{1}$, Esengul ERIM ${ }^{2}$, Zehra TOKTAY², Erdogan OZTURK*2 \\ ${ }^{1}$ Kastamonu University, Genetic and Bioengineering Department, 37150 Kastamonu, Turkey \\ ${ }^{2}$ Ataturk University, Faculty of Agriculture, Department of Field Crops, 25240, Erzurum, Turkey \\ *Corresponding author: erozturk@atauni.edu.tr
}

Received: 19.04.2021

\begin{abstract}
Mustard grows in many parts of the world thanks to its ability to adapt to different climatic conditions. It has the potential to be an important oilseed plant especially in the east of Turkey. There is scarcely any information available about fertilization in mustard cultivation in Turkey. Nitrogen and phosphorus fertilizers, a good source of nutrients for the soil, have a positive effect on the growth, development, and yield of the plant in case they are applied at the optimum level. This study was carried out in 2015 and 2016 with the purpose of examining the effects of nitrogen and phosphorus fertilization on the yield and agronomic characteristics of mustard. Five doses of nitrogen $\left(0,50,100,150,200 \mathrm{~kg} \mathrm{ha}^{-1}\right)$ and phosphorus $\left(0,30,60,90,120 \mathrm{~kg} \mathrm{ha}^{-1}\right)$ were tested. It was found that the nitrogen and phosphorus applications had significant effects on the plant growth, yield, and yield components in both 2015 and 2016. The characteristics examined within the scope of the study were significantly affected by the applications, and the oil content and seed yield increased with the increasing fertilizer doses. The results of the study emphasize the importance of fertilizer applications for the mustard plants grown in semiarid climates. $200 \mathrm{~kg} \mathrm{ha}^{-1}$ of nitrogen and $120 \mathrm{~kg} \mathrm{ha}^{-1}$ of phosphorus were found to yield better results, and it was observed that the seed yield of mustard could be increased by increasing the doses of nitrogen and phosphorus.
\end{abstract}

Keywords: Mustard, fertilization, nitrogen use efficiency, optimum fertilizer dose

\section{INTRODUCTION}

Brassicaceae family includes many economic species, especially edible ones, those cultivated for industrial oil, spices, forage plants, and vegetable species. The most important of these species are rapeseed and mustard. Two species of mustard Sinapis alba L. and Sinapis arvensis L. widely found in Turkey belong to Cruciferae family (Kayacetin et al., 2019). Wild mustard, a weed seen among the cultivated plants in wild environments and fields (Mao et al., 2012), is not grown for oil production in Turkey. Due to the high content of erucic acid in its oil (Jham et al., 2009), mustard is not suitable as a food. While a low content of erucic acid is necessary for human health, a high content is required for industrial use (Metzger and Bornscheuer, 2006; Wang et al., 2010; Li et al., 2014). In this regard, mustard is suitable for industrial use and can be considered as an alternative energy plant thanks to its capacity to provide raw materials for biodiesel production (Blackshaw et al., 2011; Khan et al., 2011; Ahmad et al., 2012).

Today, increasing environmental pollution and decreasing oil reserves have led researchers to study alternative fuels. Besides, it is very important for the energy-dependent countries to research alternative energy sources to get rid of this dependence (Nabi et al., 2006). Wild mustard is one of the plants that can be used as an alternative energy source. Cultivated plants can perform differently in different ecologies. Therefore, different plant varieties need different types and amounts of fertilizers depending on where they are grown.

Cultivated plants'rate of utilization of nutrients depends on the amount of fertilizer and when and how it is administered as well as the factors such as the soil structure, plant type and variety, precipitation and soil moisture, organic matter and nutrient content. Nitrogen and phosphorus fertilizers are effective nutrients in terms of not only the plant growth and yield but also the grain quality.

Nitrogen and phosphorus are important for mustard, as in many plants, in that they form the basis of photosynthetic processes, cell growth, metabolism, and protein synthesis (Chapin et al., 2000). Not only the amount of the nutrients in the soil but also the nutrient balance is important for producing agricultural plants in a high quality and quantity.

Nitrogen and phosphorus fertilizers are a good source of nutrients for the soil and have a positive effect on the 
growth, development, and yield of the plant in case they are applied at the optimum doses. Duval (2015) reported that nitrogen fertilizer increased the seed yield by $15-85 \%$ depending on the increasing doses $(0,56,112,168$, and 224 $\mathrm{kg} \mathrm{ha}^{-1}$ ) in yellow mustard (Sinapis alba L.). Patel et al. (2004) asserted that as the dose of nitrogen increased the oil content of Indian mustard decreased and its seed yield increased. Similarly, Mozaffari et al. (2012) reported that the highest dose of nitrogen provided the highest seed yield, 1000 -seed weight, oil content and yield in the mustard (Brassica juncea L.).

Phosphorus is the second most deficient nutrient element after nitrogen in terms of plant productivity in soils. Rodriguez et al. (2000) reported that the leaf area decreased by $83 \%$ and photosynthesis efficiency decreased by $50 \%$ in the plants grown under phosphorus stress. In the previous studies on mustard (Brassica juncea L.), the highest plant height, number of pods per plant, number of seeds per pod, 1000-seed weight, seed yield, oil content and yield were reported be obtained from the highest doses of phosphorus, that is, $60 \mathrm{~kg} \mathrm{ha}^{-1}$ (Mir et al., 2010; Singh and Thenua, 2016) and $50 \mathrm{~kg} \mathrm{ha}^{-1}$ (Solanki et al., 2015).

On the other hand, it was reported that the highest yield was obtained from the combined use of $100 \mathrm{~kg} \mathrm{ha}^{-1}$ of nitrogen and $50 \mathrm{~kg} \mathrm{ha}^{-1}$ of phosphorus in Brassica juncea (Khan et al., 2000) and the combined use of $240 \mathrm{~kg} \mathrm{ha}^{-1}$ of $\mathrm{N}$ and $88 \mathrm{~kg} \mathrm{ha}^{-1}$ of $\mathrm{P}$ in rapeseed (Brennan and Bolland, 2009; Vicianová et al., 2020).

In addition to many oil plants used in the production of alternative fuels, it is important to cultivate Sinapis arvensis and introduce it to the agriculture. There is scarcely any research on mustard production, and there is a need for basic information on its cultivation. The purpose of this study, which was carried out to contribute to meeting this need, was to create a diversity of raw materials in vegetable oil production by introducing wild mustard as an oil plant and determine the effects of different doses of nitrogen and phosphorus on the yield and quality characteristics of wild mustard in the summer growing period.

\section{MATERIALS AND METHODS}

Field experiments were carried out at the Plant Production Application and Research Center (39 $97^{\prime} \mathrm{N}$ and $41^{\circ} 67^{\prime} \mathrm{E}$; $1663 \mathrm{~m}$ above sea level), Ataturk University in Erzurum in 2015 and in 2016. The soil of two experimental sites was a silty loam (fine, mixed, mesic ustorthents) with $\mathrm{pH} 7.5,0.71 \%$ organic matter, $65 \mathrm{~kg} \mathrm{ha}^{-1}$ available $\mathrm{P}$ and $2346 \mathrm{~kg} \mathrm{ha}^{-1}$ available $\mathrm{K}$ in 2015 and $\mathrm{pH} 7.7,0.67 \%$ organic matter, $69 \mathrm{~kg} \mathrm{ha}^{-1}$ available $\mathrm{P}$ and $2355 \mathrm{~kg} \mathrm{ha}^{-1}$ available $\mathrm{K}$ in 2016 Temperature, rainfall, and relative humidity data during the crop-growing period is presented in Figure 1.

Air temperatures during the two growing seasons were higher to the long-term mean. April to September temperature, which averages $16.2{ }^{\circ} \mathrm{C}$ were slightly above normal in 2015 and 2016 There was considerable variability in rainfall amounts and distribution from year to year. The 2015 and 2016 rainfall was above the long-term average. The average rainfall for $2016(184.8 \mathrm{~mm})$ was higher than that observed $(154.6 \mathrm{~mm})$ in 2015.

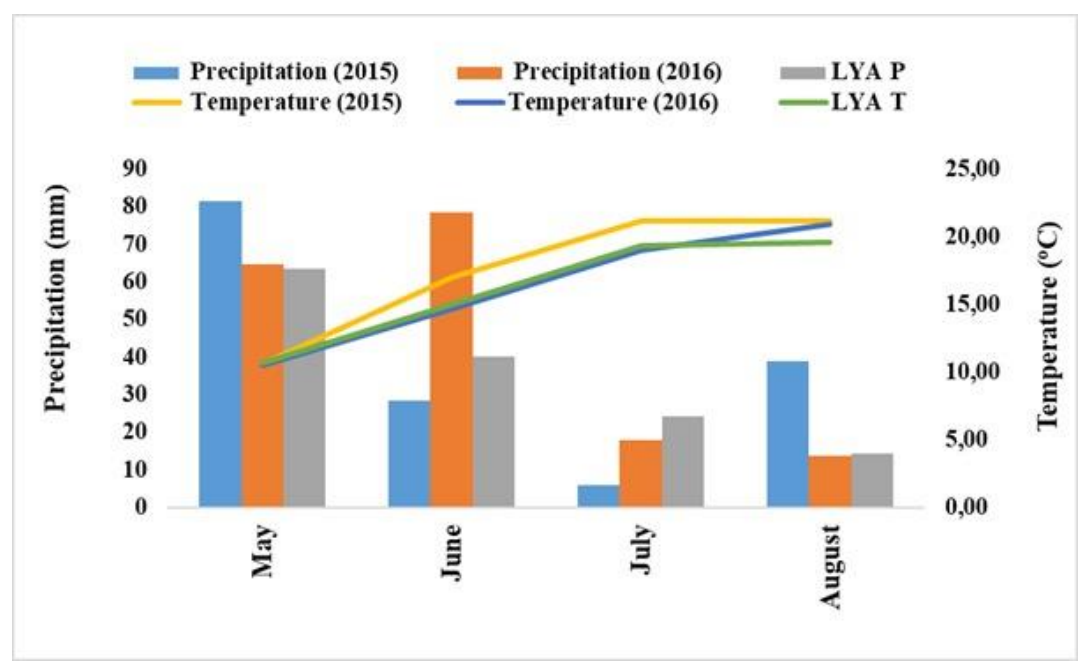

Figure 1. Some important climate data for the experimental sites in the long term and 2015-2016

In both experiments, the previous crop on the plots planted in 2015 and 2016 was barley (Hordeum vulgare L.) and wheat (Triticum vulgare L.) The plot areas were moldboard plowed in the fall and cultivated twice in the spring. In this study, mustard population was obtained from Eastern Anatolia Agricultural Research Institute.

The study, which examined the effect of nitrogen $(\mathrm{N})$ and phosphorus $(\mathrm{P})$ fertilizers on the mustard population, was designed as a coincidence blocks trial and carried out with 3 replications in 2015 and 2016. Before the planting in both years, the nitrogen-containing fertilizers in the form of ammonium sulfate and the phosphorus- containing fertilizers in the form of triple super phosphate $\left(\mathrm{P}_{2} \mathrm{O}_{5}\right)$ were uniformly applied to the seedbed by spreading and mixed into the soil at the nitrogen doses of $0,50,100,150$, and $200 \mathrm{~kg} \mathrm{ha}^{-1}$ and at the phosphorus doses of $0,30,60,90$, 
and $120 \mathrm{~kg} \mathrm{ha}^{-1}$. The plants were planted on May 7 and 8 in 2015 and 2016.

Weeds were controlled both mechanically and by hand using hoe. All plots were furrow irrigated regularly to avoid drought stress. Each irrigation brought the soil moisture back to near field capacity. Water was applied uniformly to all plots. The mustard plants were hand-harvested at the physiological maturation stage when the back of the sunflower head has turned from green to yellow and the bracts are turning brown. The dates were as follows 17 and September in 2015 and 2016 years. In the study, plant height $(\mathrm{cm})$, number of lateral branches (branch plant-1), number of pods per plant (pod plant-1), number of seeds per pod (seed pod-1) were measured in randomly selected twenty plants and the amount of seed obtained from each plot was converted into hectare and seed yield (kg ha-1) was calculated. Average values was calculated on 100 seed taken three replicates and 1000 seed weight $(\mathrm{g})$ was calculated based on multiplication by 10 . Firstly, the nitrogen content was determined by the Kjeldahl method. Then, the protein content was determined by multiplying the value determined in Kjeldahl method by the coefficient of 6.25. Oil content was determined by petroleum ether extraction in Soxhlet Apparatus.

All the data was analyzed using the SPSS package ((SPSS, Version 20.0, SPSS Inc, Chicago, IL, USA). When the F-test indicated statistical significance at the $p=0.05$ level, the protected least significant difference (Protected DUNCAN) was used to separate the means (Steel and Torrie, 1980).

\section{RESULTS AND DISCUSSION}

It was found that there were statistically significant differences $(p<0.01)$ between the years in terms of the characteristics examined within the scope of the study (Table 1). In the first growing season, when the results obtained from all the doses of nitrogen and phosphorus were averaged, the seed yield and yield components were found to have lower values. The production season in 2015 was drier and cooler than in 2016 (Figure 1). The insufficient rainfall in 2015 negatively affected the growth of mustard plants.

Table 1. Analysis results of the mustard plants to which different doses of nitrogen and phosphorus fertilizers were applied

\begin{tabular}{|c|c|c|c|c|c|c|c|c|c|}
\hline $\begin{array}{c}\text { Sources of } \\
\text { Variation }\end{array}$ & DF & $\begin{array}{c}\text { Plant } \\
\text { height } \\
(\mathrm{cm})\end{array}$ & $\begin{array}{c}\text { Number of } \\
\text { lateral } \\
\text { branches } \\
\text { (branch plant } \\
\text { 1) }\end{array}$ & $\begin{array}{l}\text { Number of } \\
\text { pods per } \\
\text { plant } \\
\text { (pod plant } \\
1 \text { ) }\end{array}$ & $\begin{array}{l}\text { Number of } \\
\text { seeds per } \\
\text { pod (seed } \\
\left.\text { pod }^{-1}\right)\end{array}$ & $\begin{array}{l}\text { 1000- } \\
\text { seed } \\
\text { weight } \\
(\mathrm{g})\end{array}$ & $\begin{array}{c}\text { Seed } \\
\text { yield } \\
(\%)\end{array}$ & $\begin{array}{c}\text { Oil } \\
\text { content } \\
(\%)\end{array}$ & $\begin{array}{c}\text { Protein } \\
\text { content } \\
(\%)\end{array}$ \\
\hline Year $(Y)$ & 1 & $* *$ & $* *$ & $* *$ & $* *$ & $* *$ & $* *$ & $* *$ & $* *$ \\
\hline Nitrogen $(\mathbf{N})$ & 4 & $* *$ & $* *$ & $* *$ & $* *$ & $* *$ & $* *$ & $* *$ & $* *$ \\
\hline Phosphorus (P) & 4 & ns & $* *$ & $* *$ & ns & $* *$ & $* *$ & $* *$ & $* *$ \\
\hline $\mathbf{Y} \times \mathbf{N}$ & 4 & ns & $* *$ & ns & ns & $* *$ & ns & $* *$ & $* *$ \\
\hline $\mathbf{Y} \times \mathbf{P}$ & 4 & ns & ns & ns & ns & $* *$ & ns & $* *$ & $* *$ \\
\hline $\mathbf{N} \times \mathbf{P}$ & 16 & $* *$ & $* *$ & $* *$ & $* *$ & $* *$ & $* *$ & $* *$ & $* *$ \\
\hline $\mathbf{Y} \times \mathbf{N} \times \mathbf{P}$ & 16 & ns & ns & ns & ns & $* *$ & ns & $* *$ & $* *$ \\
\hline
\end{tabular}

** significant at 0.01 . NS, nonsignificant.

\section{Plant height}

In the study, the effects of year, nitrogen doses, and the interaction between nitrogen doses and phosphorus doses on plant height were found to be significant $(\mathrm{p}<0.01)$ (Table 1). The plant height was found to be higher in 2016 (86.1 $\mathrm{cm})$ than in $2015(82.1 \mathrm{~cm})$, possibly due to the changing climatic factors (Figure 1). Montemurro et al. (2007) reported that sufficient rainfall during growing season increased the initial vegetative growth of the plant. The nitrogen fertilizer applications caused an increase in the plant height compared to the plants grown without fertilizer (control). Applying 50, 100, 150, and $200 \mathrm{~kg} \mathrm{ha}^{-1}$ of nitrogen increased the plant height by $8.8 \%, 9.4 \%, 10.0 \%$, and $16.9 \%$, respectively, compared to the control. So, the plant heights varied significantly depending on the dose of nitrogen. Nitrogenous fertilizers increase the vegetative development in the plant and, by doing so, increase the plant height. Khan et al. (2000), Keivanrad and Zandi (2012) reported that the increase in nitrogen doses positively affected the plant height and the higher values were obtained from the highest nitrogen dose. It was found that the responses to the nitrogen doses were different from those to the phosphorus doses, and the application of phosphorus fertilizer ( 30 and $120 \mathrm{~kg} \mathrm{ha}^{-1}$ ) had a negative effect on the plant height and caused a decrease by 0.1 and $0.3 \%$ on average. The plant height was found to be higher at the phosphorus dose of $90 \mathrm{~kg} \mathrm{ha}^{-1}(84.5 \mathrm{~cm})$ than the other phosphorus doses (Table 1). However, this difference was not statistically significant $(\mathrm{p}<0.01)$. The reason why the plant height was higher at the phosphorus dose of $90 \mathrm{~kg}$ $\mathrm{ha}^{-1}$ may be because the plant could effectively absorb the phosphorus, thanks to its developing root system, until it matured (Sigh and Thenua, 2016). It was reported that the phosphorus applications had an irregular effect on the plant height, and the increasing doses of phosphorus did not affect the plant height (Tucturk, 2008; Deniz, 2019).

\section{Number of lateral branches}

The number of branches depends on the interaction of the plant, environmental conditions, and genetic structure, and contributes positively to the yield. In the study, it was found that the year, nitrogen applications, the interactions "year x nitrogen dose" and "nitrogen dose x phosphorus 
dose" significantly affected the number of lateral branches per plant $(\mathrm{p}<0.01)$. The number of lateral branches of mustard plant was found to be 2.9 in 2015 and 3.5 branch plant $^{-1}$ in 2016. It can be asserted that the ecological factors played a significant role in the number of branches of the mustard plants. Rainfall and temperature were appropriate in 2016 (Figure 1), especially during the flowering period, and this might have increased the number of branches. The effects of the nitrogen applications on the number of lateral branches per plant varied over the years. The effects of the same doses of nitrogen applications on the number of lateral branches per plant differed by year. This was due to the climatic characteristics that varied by month (Figure 1). All the nitrogen applications caused an increase in the number of lateral branches per plant compared to the control, and $200 \mathrm{~kg} \mathrm{ha}^{-1}$ of nitrogen caused the highest increase (158.8\%) (Table 2). It was found that the number of lateral branches in the plants significantly increased with the increasing doses of nitrogen (Khan et al., 2000; Patel et al., 2004; Shorma et al., 2020). It was reported that the increasing doses of nitrogen improved the availability of proteins and protoplasm formation, helped in mitotic division, and by doing so, increased the number of branches (Shorna et al., 2020). This increase is a result of the relationship between nitrogen and plant growth. As the phosphorus dose increased the number of lateral branches per plant increased until the dose of $90 \mathrm{~kg} \mathrm{ha}^{-1}$, and the number of lateral branches per plant were observed at the dose of $120 \mathrm{~kg} \mathrm{ha}^{-1}$, the highest phosphorus dose (Table 2). There were no significant differences between the doses of phosphorus in terms of the number of lateral branches per plant; so, the effect of phosphorus fertilizer was found to be statistically insignificant. Tuncturk (2008) reported that the different doses of phosphorus fertilizer did not affect the number of lateral branches per plant in rapeseed.

\section{Number of pods per plant}

It was found that the year, applications of nitrogen and phosphorus, and the interaction "nitrogen dose $x$ phosphorus dose" significantly affected the number of pods per plant $(p<0.01)$, which is one of the important determinant factors in seed yield. The mean number of pods was found to be 46.1 in 2015 and 51.4 pod plant $^{-1}$ in 2016 . The number of pods in the second year of the study was about 5.3 pod plant ${ }^{-1}$ more than that in the first year. The reason why the number of pods per plant was low in the first year of the study may be due to the adverse environmental factors in the first growth period, especially during the early flowering period (Figure 1). The number of pods per plant, which is positively correlated with the yield, positively responded to the increasing doses of nitrogen. The greatest response was observed at $200 \mathrm{~kg}$ ha ${ }^{1}(148.3 \%)$, the highest dose of nitrogen (Table 2 ). The soils used in the study were poor in organic matter and the study was carried out under irrigated conditions, which explains the differences between the nitrogen doses. As is the case with nitrogen doses, different doses of phosphorus significantly affected the number of pods per plant (Khan et al., 2000). The number of pods increased (54.6 pod plant $^{-}$ ${ }^{1}$ ) in the second dose of the phosphorus fertilizer, but after this dose it decreased. The lowest value (42.1 pod plant ${ }^{-1}$ ) was observed at the highest dose of phosphorus (Table 2). The response to the nitrogen doses was different from that to the phosphorus doses, and this caused the interaction "nitrogen dose $\mathrm{x}$ phosphorus dose" to be significant in terms of the number of pods. While the application with no nitrogen and $120 \mathrm{~kg} \mathrm{ha}^{-1}$ of phosphorus yielded the lowest number of pods ( 15.5 pod plant- $\left.{ }^{1}\right)$, the application with 200 $\mathrm{kg} \mathrm{ha}^{-1}$ of nitrogen and $30 \mathrm{~kg} \mathrm{ha}^{-1}$ of phosphorus yielded the highest number of pods ( 83.8 pod plant $\left.{ }^{1}\right)$. Keivanrad and Zandi (2012) and Panotra et al. (2016) reported that the increasing doses of nitrogen applied to mustard and rapeseed increased the number of pods. Cheema et al. (2001), Tahir et al. (2003), and Mir et al. (2010) reported that the number of pods was observed to be the highest in the second-high dose of phosphorus fertilizer. Keivanrad and Zandi (2012) reported the number of pods as 105.6, Panotra et al. (2016) as 430.42-491.14, and Kayacetin et al. (2017) as 21.1-116.0. These results are considerably higher than our results due to the differences in mustard varieties and ecological factors.

\section{Number of seeds per pod}

In cultivated plants, the number of seeds per pod, one of the most important yield factors that directly affect the grain yield, varies depending on the year and the dose of the nitrogen application. Due to the fact that in 2015, in the first week of July, the flowering period of the plant, there was almost no rainfall and the temperature was high; the number of seeds per pod was found to be lower in 2015 $\left(15.1\right.$ seed pod $\left.^{-1}\right)$ than in 2016 (16.5 seed pod ${ }^{-1}$ ) (Figure 1 and Table 3). In the study, the number of seeds per pod tented to increase markedly with the increasing doses of nitrogen. Panotra et al. (2016) and Cheema et al. (2001) also found that the number of seeds increased as the dose of nitrogen increased, and they emphasized that this difference could be due to the role of nitrogen in growth. Although the application of $150 \mathrm{~kg} \mathrm{~N}$ per hectare caused a considerable increase in the number of seeds per pod, the dose of $200 \mathrm{~kg}$ N per hectare did not cause much difference. This result suggests that the positive effect of nitrogen on the number of seeds per pod decreases in case it is applied excessively. $120 \mathrm{~kg} \mathrm{ha}^{-1}$ of phosphorus application yielded the highest number of seeds per pod $\left(16.3\right.$ seed pod $\left.^{-1}\right)$ which was $1.2 \%$ more than the control (Table 3 ). The number of seeds per pod was not significantly affected by the applications of phosphorus fertilizer; however, it was higher in the phosphorus doses of 0,30 , and $120 \mathrm{~kg} \mathrm{ha}^{-1}$

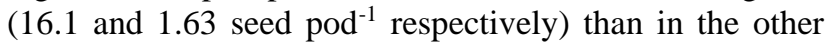
doses. (Table 3). In the previous studies on rapeseed (Tuncturk, 2008; Karaaslan, 1999), it was reported that increasing phosphorus doses positively increased the number of seeds in rapeseed and carob, but this increase was irregular. When all the factors were considered together, it was found that the number of seeds per pod was found to be the highest $\left(19.9\right.$ seed pod $\left.^{-1}\right)$ in the application with $150 \mathrm{~kg} \mathrm{ha}^{-1}$ of nitrogen and no phosphorus and the lowest $\left(13.0\right.$ seed pod $\left.^{-1}\right)$ in the application with no nitrogen and $60 \mathrm{~kg} \mathrm{ha}^{-1}$ of phosphorus. The response to the nitrogen 
doses was different from that to the phosphorus doses, and this caused the interaction "nitrogen dose $\mathrm{x}$ phosphorus dose" to be significant in terms of the number of seeds per pod.

Table 2. Effect of the nitrogen and phosphorous applications at different doses on plant height, number of lateral branches, number of pods per plant, number of seeds per pod, thousand seed weight, and seed yield in oilseed mustard.

\begin{tabular}{|c|c|c|c|c|c|c|c|c|c|}
\hline \multicolumn{2}{|c|}{ Treatments } & $\begin{array}{c}\text { Plant } \\
\text { height } \\
(\mathrm{cm})\end{array}$ & $\begin{array}{c}\text { Number } \\
\text { of lateral } \\
\text { branches } \\
\text { (branch }^{-1} \\
\text { plant }^{-1} \text { ) }\end{array}$ & $\begin{array}{l}\text { Number } \\
\text { of pods } \\
\text { per plant } \\
(\text { pod } \\
\left.\text { plant }^{-1}\right)\end{array}$ & $\begin{array}{c}\text { Number } \\
\text { of seeds } \\
\text { per pod } \\
(\text { seed } \\
\left.\text { pod }^{-1}\right)\end{array}$ & $\begin{array}{l}1000- \\
\text { seed } \\
\text { weght } \\
\text { (g) }\end{array}$ & $\begin{array}{c}\text { Seed } \\
\text { yield } \\
\left(\mathbf{k g ~ h a}^{-1}\right)\end{array}$ & $\begin{array}{c}\text { Oil } \\
\text { content } \\
(\%)\end{array}$ & $\begin{array}{c}\text { Protein } \\
\text { content } \\
(\%)\end{array}$ \\
\hline \multirow{2}{*}{ Year } & 2015 & $82.1 \mathrm{~b}$ & $2.9 \mathrm{~b}$ & $46.1 \mathrm{~b}$ & $15.1 \mathrm{~b}$ & $1.5 \mathrm{~b}$ & $630.5 \mathrm{~b}$ & $16.4 \mathrm{~b}$ & $26.4 \mathrm{a}$ \\
\hline & 2016 & $86.1 \mathrm{a}$ & $3.5 \mathrm{a}$ & $51.4 \mathrm{a}$ & $16.5 \mathrm{a}$ & $2.0 \mathrm{a}$ & $710.0 \mathrm{a}$ & $19.0 \mathrm{a}$ & $24.2 \mathrm{~b}$ \\
\hline \multicolumn{2}{|l|}{ Mean } & 84.1 & 3.2 & 48.8 & 15.8 & 1.8 & 670.3 & 17.7 & 25.3 \\
\hline \multirow{5}{*}{$\begin{array}{l}\text { Nitrogen dose } \\
\quad\left(\mathrm{kg} \mathrm{ha}^{-1}\right)\end{array}$} & $\mathbf{0}\left(\mathrm{N}_{1}\right)$ & $77.5 \mathrm{c}$ & $1.7 \mathrm{e}$ & $26.5 \mathrm{~d}$ & $14.4 \mathrm{c}$ & $1.6 \mathrm{~d}$ & $360.4 \mathrm{e}$ & $14.2 \mathrm{~d}$ & $21.6 \mathrm{~d}$ \\
\hline & $50\left(\mathbf{N}_{2}\right)$ & $83.8 \mathrm{~b}$ & $3.0 \mathrm{~d}$ & $40.5 \mathrm{c}$ & $15.7 \mathrm{~b}$ & $1.6 \mathrm{~d}$ & $650.3 \mathrm{~d}$ & $18.2 \mathrm{a}$ & $24.2 \mathrm{c}$ \\
\hline & $100\left(\mathrm{~N}_{3}\right)$ & $84.0 \mathrm{~b}$ & $3.5 \mathrm{c}$ & $49.0 \mathrm{~b}$ & $15.5 \mathrm{c}$ & $1.7 \mathrm{c}$ & $750.6 \mathrm{~b}$ & $17.7 \mathrm{~b}$ & $25.1 \mathrm{~b}$ \\
\hline & $150\left(N_{4}\right)$ & $85.0 \mathrm{~b}$ & $3.7 \mathrm{~b}$ & $61.5 \mathrm{a}$ & $16.7 \mathrm{a}$ & $1.8 \mathrm{~b}$ & $680.8 \mathrm{c}$ & $15.6 \mathrm{c}$ & $27.7 \mathrm{a}$ \\
\hline & $200\left(N_{5}\right)$ & $90.3 \mathrm{a}$ & $4.4 \mathrm{a}$ & $65.8 \mathrm{a}$ & $16.9 \mathrm{a}$ & $1.9 \mathrm{a}$ & $900.1 \mathrm{a}$ & $17.8 \mathrm{ab}$ & $27.9 \mathrm{a}$ \\
\hline \multicolumn{2}{|l|}{ Mean } & 84.1 & 3.3 & 48.7 & 15.8 & 1.7 & 668.4 & 16.7 & 25.3 \\
\hline \multirow{5}{*}{$\begin{array}{l}\text { Phosphorus dose } \\
\quad\left(\mathrm{kg} \mathrm{ha}^{-1}\right)\end{array}$} & $\mathbf{0}\left(\mathbf{P}_{1}\right)$ & 84.3 & 3.2 & $50.5 \mathrm{ab}$ & 16.1 & $1.8 \mathrm{a}$ & $750.2 \mathrm{~b}$ & $14.7 \mathrm{~d}$ & $24.8 \mathrm{c}$ \\
\hline & $30\left(\mathbf{P}_{2}\right)$ & 84.2 & 3.3 & $54.6 \mathrm{a}$ & 16.1 & $1.8 \mathrm{a}$ & $550.1 \mathrm{e}$ & $17.3 \mathrm{~b}$ & $25.0 \mathrm{c}$ \\
\hline & $60\left(P_{3}\right)$ & 84.5 & 3.3 & $50.1 \mathrm{bc}$ & 15.4 & $1.7 \mathrm{~b}$ & $570.9 \mathrm{c}$ & $16.3 \mathrm{c}$ & $26.6 \mathrm{a}$ \\
\hline & $90\left(\mathbf{P}_{4}\right)$ & 84.6 & 3.4 & $45.8 \mathrm{~cd}$ & 15.2 & $1.8 \mathrm{a}$ & $690.3 \mathrm{c}$ & $16.6 \mathrm{c}$ & $25.4 \mathrm{~b}$ \\
\hline & $120\left(P_{5}\right)$ & 84.0 & 3.1 & $42.1 \mathrm{~d}$ & 16.3 & $1.6 \mathrm{c}$ & $800.1 \mathrm{a}$ & $18.7 \mathrm{a}$ & $24.8 \mathrm{c}$ \\
\hline \multicolumn{2}{|l|}{ Mean } & 84.3 & 3.3 & 48.6 & 15.8 & 1.7 & 672.3 & 16.7 & 25.3 \\
\hline \multirow{25}{*}{ Interaction (N x P) } & $\mathbf{N}_{1} \mathbf{P}_{1}$ & 83.3 & 1.8 & 26.2 & 16.2 & 1.5 & 480.0 & 13.0 & 18.3 \\
\hline & $\mathbf{N}_{1} \mathbf{P}_{2}$ & 73.6 & 2.0 & 35.2 & 13.8 & 2.0 & 290.8 & 13.8 & 27.5 \\
\hline & $\mathbf{N}_{1} \mathbf{P}_{3}$ & 85.9 & 2.2 & 32.6 & 13.0 & 2.1 & 330.1 & 13.7 & 24.9 \\
\hline & $\mathbf{N}_{1} \mathbf{P}_{4}$ & 72.6 & 1.6 & 23.0 & 14.6 & 2.3 & 430.5 & 14.1 & 23.0 \\
\hline & $\mathbf{N}_{1} \mathbf{P}_{5}$ & 72.2 & 1.0 & 15.4 & 14.4 & 1.8 & 270.6 & 16.6 & 27.2 \\
\hline & $\mathbf{N}_{2} \mathbf{P}_{1}$ & 78.4 & 2.9 & 41.0 & 13.5 & 1.5 & 770.4 & 17.1 & 21.7 \\
\hline & $\mathbf{N}_{2} \mathbf{P}_{2}$ & 79.8 & 2.1 & 26.0 & 17.2 & 1.5 & 520.4 & 20.5 & 21.8 \\
\hline & $\mathbf{N}_{2} \mathbf{P}_{3}$ & 84.8 & 3.8 & 60.6 & 15.5 & 1.5 & 600.0 & 16.5 & 22.1 \\
\hline & $\mathbf{N}_{2} \mathbf{P}_{4}$ & 85.9 & 3.0 & 33.7 & 14.5 & 1.9 & 530.0 & 18.5 & 20.6 \\
\hline & $\mathbf{N}_{2} \mathbf{P}_{5}$ & 90.3 & 3.0 & 41.3 & 17.4 & 1.8 & 830.7 & 18.5 & 21.9 \\
\hline & $\mathbf{N}_{3} \mathbf{P}_{1}$ & 83.2 & 3.2 & 48.4 & 15.6 & 2.1 & 1030.3 & 14.0 & 26.8 \\
\hline & $\mathbf{N}_{3} \mathbf{P}_{2}$ & 89.2 & 3.6 & 61.4 & 14.7 & 1.7 & 810.7 & 18.7 & 21.8 \\
\hline & $\mathbf{N}_{3} P_{3}$ & 76.8 & 3.0 & 37.9 & 15.5 & 1.5 & 480.8 & 17.2 & 26.5 \\
\hline & $\mathbf{N}_{4} \mathbf{P}_{4}$ & 86.3 & 4.2 & 55.2 & 14.5 & 1.2 & 700.0 & 17.4 & 28.5 \\
\hline & $\mathbf{N}_{5} P_{5}$ & 84.3 & 3.3 & 42.3 & 16.7 & 1.6 & 810.2 & 21.0 & 21.8 \\
\hline & $\mathbf{N}_{4} \mathbf{P}_{1}$ & 88.7 & 3.9 & 81.4 & 19.9 & 1.9 & 780.5 & 12.2 & 28.3 \\
\hline & $\mathbf{N}_{4} \mathbf{P}_{2}$ & 85.1 & 3.9 & 62.4 & 17.6 & 2.0 & 570.8 & 18.9 & 26.1 \\
\hline & $\mathbf{N}_{4} \mathbf{P}_{3}$ & 83.5 & 3.4 & 64.6 & 15.6 & 1.6 & 660.1 & 16.9 & 31.3 \\
\hline & $\mathbf{N}_{4} \mathbf{P}_{4}$ & 85.0 & 3.6 & 47.2 & 15.6 & 1.6 & 540.5 & 12.6 & 28.0 \\
\hline & $\mathbf{N}_{4} \mathbf{P}_{5}$ & 82.5 & 3.7 & 51.7 & 14.6 & 1.5 & 870.1 & 17.7 & 25.0 \\
\hline & $\mathbf{N}_{5} P_{1}$ & 88.1 & 4.6 & 55.5 & 15.4 & 2.1 & 690.0 & 17.3 & 29.7 \\
\hline & $\mathbf{N}_{5} \mathbf{P}_{2}$ & 90.1 & 5.0 & 88.4 & 17.2 & 1.7 & 530.8 & 14.8 & 26.7 \\
\hline & $\mathbf{N}_{5} \mathbf{P}_{3}$ & 90.0 & 3.4 & 54.8 & 17.6 & 1.7 & 810.7 & 17.2 & 28.1 \\
\hline & $\mathbf{N}_{5} P_{4}$ & 92.5 & 4.4 & 69.9 & 17.3 & 2.3 & 1250.3 & 20.4 & 26.7 \\
\hline & $\mathbf{N}_{5} P_{5}$ & 90.9 & 4.6 & 60.2 & 17.2 & 1.5 & 1200.8 & 19.6 & 28.1 \\
\hline $\mathrm{Cv}$ & & 3.3 & 8.7 & 6.7 & 7.3 & 6.6 & 3.6 & 3.1 & 6.4 \\
\hline
\end{tabular}

For each main effect, the values within the columns followed by the same letter are not significant.

\section{0-seed weight}

Since a positive correlation exists between grain weight and yield, 1000-seed weight is commonly used a major determinant of mustard yield. The fuller and larger seeds have a higher 1000-seed weight, and as a result, have a higher yield. Seed weight differed depending on various growing seasons and conditions. In this study, 1000-seed weight significantly differed between 2015 and 2016. The 1000 -seed weight was found to be $1.5 \mathrm{~g}$ in 2015 and $2.0 \mathrm{~g}$ 
in 2016. Seed weight is directly associated with the climatic conditions, especially during the flowering period. In 2015, in the first week of July, the flowering period of the plant, there was almost no rainfall and the temperature was high. This might have caused the low seed weight in 2015 (Figure 1 and Table 1). Beyyavas et al. (2011) reported that genotype and ecological conditions were two important factors affecting 1000-seed weight. The lowest 1000-seed weight was observed in the control and the application of $50 \mathrm{~kg} \mathrm{ha}^{-1}$ nitrogen $(1.6 \mathrm{~g})$, and the highest 1000 -seed weight was observed in the application of $200 \mathrm{~kg} \mathrm{ha}^{-1}$ nitrogen $(1.9 \mathrm{~g})$. The response of 1000 -seed weight to nitrogen was positive, and the 1000 -seed weight tended to increase with the increase in the amount of nitrogen applied (Reager et al., 2006; Keivanrad and Zandi, 2012; Mozaffari et al., 2012; Panotra et al., 2016). Finlayson et al. (1970) explained this situation by the fact that nitrogen is the most common nutrient element in the seed and has an active function in the structure of seed. In the present study, the control and $30 \mathrm{~kg} \mathrm{ha}^{-1}$ of phosphorus application yielded the highest 1000-seed weight. The 1000-seed weight decreased with the increase in the dose of phosphorus. Grain weight is controlled by the genetic structure, environment, soil fertility, and nitrogen and phosphorus in particular (Shafi et al., 1992). The response of the mustard plant to the phosphorus doses differed depending on the years, and this caused the interaction "year $\mathrm{x}$ phosphorus dose" to be significant in terms of the seed weight.

\section{Seed yield}

Seed yield is mostly a result of the cumulative effects of various yield components under the influence of environmental conditions and different agricultural practices such as fertilization. So, the seed yield is controlled by several internal and external factors. The year, nitrogen dose, and phosphorus dose had some significant effects on the seed yield $(p<0.01)$. However, the effect of all the interactions, except the interaction "nitrogen dose $\mathrm{x}$ phosphorus dose", was found to be insignificant (Table 1). The seed yield in the first year of the experiment was about $79.5 \mathrm{~kg} \mathrm{ha}^{-1}$ more than that in the second year. Vicianova et al. (2020) asserted that the seed yield was significantly affected by the climatic factors. Climatic conditions are of critical importance in the production of mustard especially in the flowering period. In this regard, the low yield in the first year of the study can be explained by the decrease in the seed set rates due to the cold weather conditions at the beginning of flowering period (late June). It is a fact that nitrogen dose has a direct effect on seed yield. In the study, different doses of nitrogen positively affected the seed yield. Compared to the control, the nitrogen doses $\left(50,100,150\right.$, and $\left.200 \mathrm{~kg} \mathrm{ha}^{-1}\right)$ increased the seed yield by $80.4 \%, 108.3 \%, 88.9 \%$, and $149.8 \%$, respectively, and the highest increase was observed in the dose of $200 \mathrm{~kg} \mathrm{ha}^{-1}$ (Table 2, Figure 2). Similarly, the seed yield increased as the dose of phosphorus fertilizer increased, and the highest yield (800.1 $\mathrm{kg} \mathrm{ha}^{-1}$ ) was observed in the phosphorus dose of $120 \mathrm{~kg} \mathrm{ha}^{-1}$ and the lowest yield $\left(550.1 \mathrm{~kg} \mathrm{ha}^{-1}\right)$ in the phosphorus dose of 30 $\mathrm{kg} \mathrm{ha}^{-1}$ (Table 2, Figure 2). The response to the nitrogen doses in terms of seed yield was different from that to the phosphorus doses, and this caused the interaction "nitrogen dose $x$ phosphorus dose" to be significant. Accordingly, the highest seed yield was observed to be in $200 \mathrm{~kg} \mathrm{ha}^{-1}$ of nitrogen and $90 \mathrm{~kg} \mathrm{ha}^{-1}$ and $120 \mathrm{~kg} \mathrm{ha}^{-1}$ of phosphorus whereas the lowest seed yield was observed to be in the control and $20 \mathrm{~kg} \mathrm{ha}^{-1}$ of phosphorus (Figure 2). It is understood that as the dose of nitrogen increased, the number of pods per plant, the number of seeds per pod, and the 1000-seed weight increased and, accordingly, the seed yield increased. The most important reason for the positive response of the mustard plant to nitrogen fertilizer may be the fact that the soil was poor in organic matter and, accordingly, in nitrogen. In other words, adding fertilizer to the soil that is insufficient in nitrogen significantly increased the seed yield in the mustard plant. Shorma et al. (2020) reported that the seed yield increased with the increase in the doses of nitrogen. Similarly, Reddy and Sinha (1989) also found that as the amount of nitrogen increased, the seed yield increased by $49.5 \%-96.5 \%$ in the mustard plant. The yield in $120 \mathrm{~kg} \mathrm{ha}^{-1}$ of phosphorus application was higher than the other applications. This increase in yield is probably due to the increased metabolic activity caused by the formation of structural carbohydrates (Said-Al Ahl et al., 2016). Supporting our results, Khan et al. (2000), McKenzie et al. (2003), and Solanki et al. (2015) reported that the higher doses of phosphorus fertilizer increased the seed yield in similar plants.

\section{Oil content}

The seed oil concentration was significantly affected by years and fertilizer applications. The oil content of the mustard plant was found to be slightly low in the first year of the study. As can be seen in the Table 1 showing the climate data for 2015 and 2016, the total amount of precipitation in May, June, and July in 2016 was markedly higher compared to 2015, which explains the high crude oil contents in 2016. Previous studies reported that the oil content was significantly affected by the temperature differences over the years, and the oil content decreased in the years when the weather was hot during the grain filling period (Weiss, 1983; Roche et al., 2004). In the present study, nitrogen and phosphours fertilization caused some differences in the seed oil concentration of mustard. The oil content generally increased as the dose of nitrogen increased, except for the control and the nitrogen dose of $150 \mathrm{~kg} \mathrm{ha}^{-1}$. The highest oil content $(18.2 \%)$ was observed to be in the nitrogen dose of $50 \mathrm{~kg} \mathrm{ha}^{-1}$ and the lowest oil content $(14.2 \%)$ in the control (Table 2, Figure 2). This result was observed in both years of the study and similar to the results of the study by Keivanrad and Zandi (2014). Mozaffari et al. (2012) reported that they obtained the highest oil contents from the highest doses of nitrogen. It was observed that the oil content increased with the increase in the dose of phosphorus. The highest oil content $\left(18.7 \%\right.$ ) was observed in the dose of $120 \mathrm{~kg} \mathrm{ha}^{-1}$, the highest phosphorus dose, and the lowest oil content (14.7\%) in the control (Table 2, Figure 2). In our study, the oil contents differed depending on the doses of nitrogen and phosphorus. The response to the nitrogen doses was 
different from that to the phosphorus doses, and this caused the interaction "nitrogen dose $\mathrm{x}$ phosphorus dose" to be significant in terms of the oil content. In the previous studies on rapeseed, it was reported that the high doses of phosphorus increased the oil content (Motlagh et al., 2012; Said-Al Ahl et al., 2016; Ahmed, 2018).

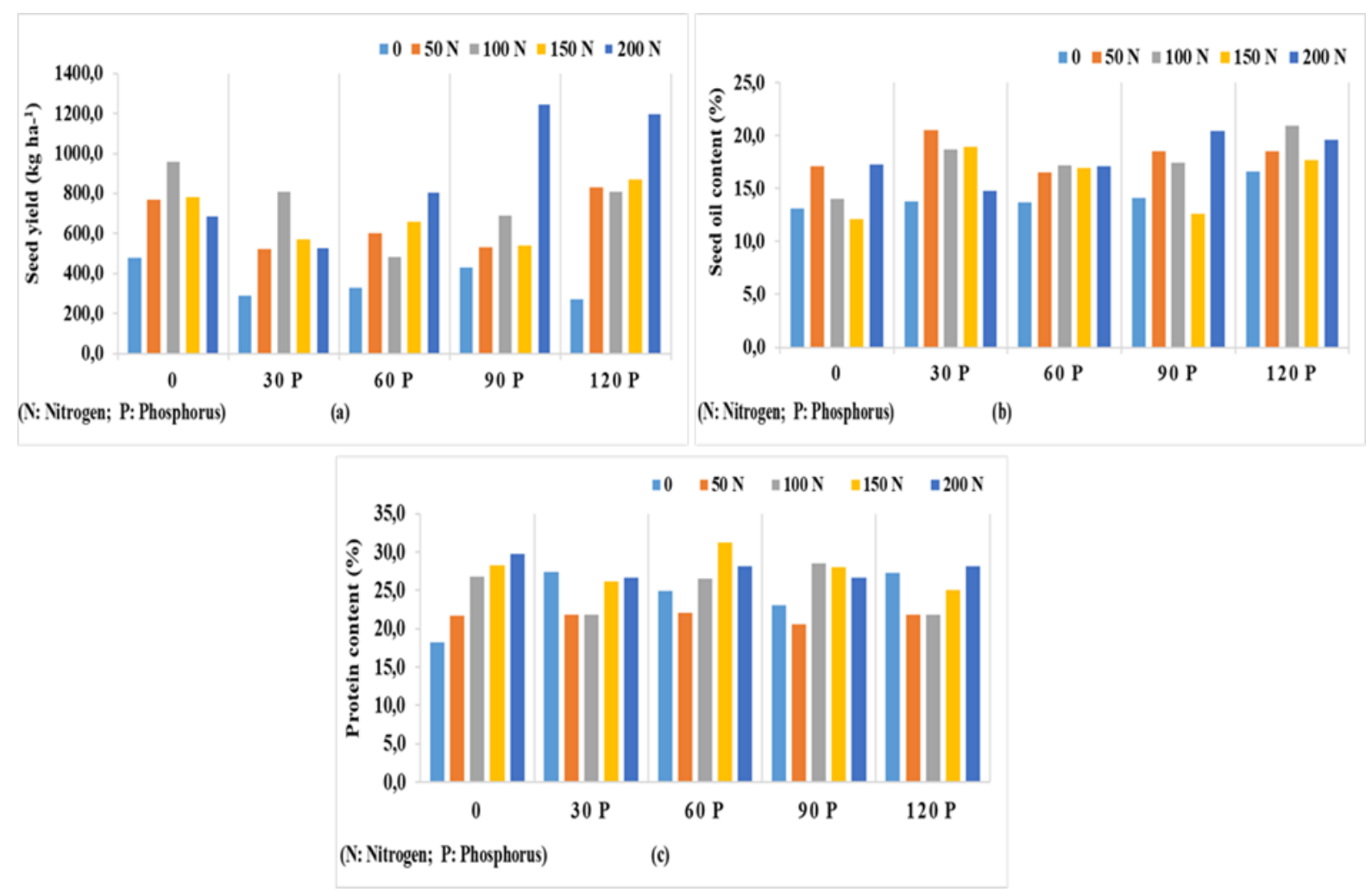

Figure 2: Effect of the dose of nitrogen $(\mathrm{N})$ and phosphorus $(\mathrm{P})$ fertilizer on the seed yield (a), seed oil content (b), and protein content (c) in mustard.

\section{Protein content}

The protein content of seeds shows their quality and nutritional value. The application of nitrogen and phosphorus fertilizers decreased the seed protein contents of the mustard in 2016. The protein contents of the mustard plants were higher in 2015 (26.4\%) than in 2016 (24.2\%). Protein content, a quality criterion in oil crops, is affected by the environmental factors such as temperature and precipitation as well as the genetic characteristics of the variety. In this study, the seed protein contents were found to differ depending on the dose of the nitrogen and phosphorus fertilizers. Crude protein contents of the seeds increased significantly with the increasing doses of nitrogen (Table 2). The highest protein content was found to be in the nitrogen doses of 150 and $200 \mathrm{~kg} \mathrm{ha}^{-1}(27.7 \%$ and $27.9 \%$, respectively), and the lowest protein content in the control (21.6\%) (Figure 2). The protein contents varied depending on the dose of the phosphorus fertilizer, and the highest protein content was found to be in the phosphorus dose of $60 \mathrm{~kg} \mathrm{ha}^{-1}(26.6 \%)$ and the lowest protein content in the phosphorus doses of 30 and $120 \mathrm{~kg} \mathrm{ha}^{-1}$ (24.8\%) (Table 2, Figure 2). It was found that the response of the mustard plant to different doses of nitrogen fertilizer was different from that to the doses of phosphorus fertilizer. Cheema et al. (2001) reported that the phosphorus applications increased the protein content in mustard.
Nitrogen is the building block of protein which is an important structural component of all plants. Therefore, the increased doses of nitrogen accelerate the protein formation and hence the growth. Kovács et al. (2009) asserted that the protein content of the seeds with high content of nitrogen increased due to the fact that the $\mathrm{N}$ content of vegetative components could be transported to the reproductive organs.

\section{CONCLUSION}

Mustard is sensitive to fertilization, so nitrogen and phosphours fertilizer were studied to maximize the yield and quality of mustard. The results of the study were in agreement with other research, indicating the effects of nitrogen and phosphorus fertilizers on the yield and agronomic characteristics. In general, the yield, yield components, and quality of mustard tended to increase with the applications of nitrogen and phosphorous. Therefore, it is important to make a good decision in choosing the right fertilizer combinations. The effect of nitrogen and phousphours fertilizers on the seed yield, yield components, and quality of mustard was found to be significant in 2015 and 2016. The nitrogen and phosphorus applications yielded different results, and there were significant differences in terms of the nitrogen and phosphorus doses. Considering the yield and the important quality criteria, the best results were obtained in the 
nitrogen dose of $200 \mathrm{~kg} \mathrm{ha}^{-1}$ and the phosphorus dose of $120 \mathrm{~kg} \mathrm{ha}^{-1}$. In conclusion, based on the data obtained in this study, it can be asserted that mustard is an important plant that can be included in the product diversity of the region thanks to its advantages such as that it has a short vegetation period, requires low input, and can be grown in the marginal areas where other cultivated plants cannot be grown. The results of the study suggest that the best results in terms of yield and yield components can be obtained from the highest doses of fertilizers in the plants such as mustard, especially in the regions where the continental climate and semi-arid climatic conditions prevail and vegetation periods are short.

\section{LITERATURE CITED}

Ahmed, R.M. 2018. Oil percent and unsaturated fatty acid respose of rapeseed cultivars to nitrogen and phosphorus fertilizers in two different sowing date. Tikrit Journal for Agricultural Science 18(4): 29-38

Ahmad, M., H. Sadia, M. Zafar, S. Sultana, M.A. Khan and Z. Khan. 2012. The production and quality assessment of mustard oil biodiesel: A cultivated potential oil seed crop. Energy Sources A: Recovery. Utilization and Environmental Effects, $34(16)$ : 1480-1490. doi.org/10.1080/15567036.2011.596907

Beyyavas, V., H. Haliloglu, O. Copur and A. Yilmaz. 2011. Determination of seed yield and yield components of some safflower (Carthamus tinctorius L.) cultivars, lines and populations under the semi-arid conditions. African Journal of Biotechnology 10(4): 527-534. doi.org/10.5897/AJB09.1395

Blackshaw, R., E. Johnson, Y. Gan, W. May, D. McAndrew, V. Barthet, T. McDonald and D. Wispinski. 2011. Alternative oilseed crops for biodiesel feedstock on the Canadian prairies. Canadian Journal of Plant Science 9(5): 889-896. doi.org/10.4141/cjps2011-002

Brennan, R.F. and M.D.A. Bolland. 2009. Comparing the nitrogen and phosphorus requirements of canola and wheat for grain yield and quality. Crop and Pasture Science 60(6): 566-577. doi.org/.10.1071/CP08401

Chapin, F.S., E.S. Zavaleta, V.T. Eviner, R.L. Naylor, P.M. Vitousek, H.L. Reynolds, D.U. Hooper, S. Lavorel, O.E.S. Sala, S.E. Hobbie, M.C. Mark and S. Diaz. 2000. Consequences of changing biodiversity. Nature 405, 234242. DOI: $10.1038 / 35012241$

Cheema, M.A., M.A. Malik, A. Hussain, S.H. Shah and S.M.A. Basra. 2001. Effects of time and rate of nitrogen and phosphorus application on the growth and the seed and oil yields of canola (Brassica napus L.) Journal of Agronomy and Crop Science 186: 103-110. DOI.10.1046/j.1439037X.2001.00463.x

Deniz, F. 2019. The effect of phosphorus fertilizer doses on the agricultural and quality characteristics of wild mustard (Brassica: Sinapis arvensis L.) at different sowing dates. Van Yuzuncu Y1l University, Institute of Natural and Applied Sciences, Department of Field Crops. Master's Thesis 2019.

Duval, A.S. 2015. Applied Nitrogen Effects on Yellow Mustard (Sinapis alba L.) Production in the Willamette Valley. Oregon State University, Master of Science thesis.

Finlayson, A.J., C.M. Christ and R.K. Downey. 1970. Changes in the nitrogenous components of rapeseed (Brassica napus) grown on a nitrogen and sulfur deficient soil. Journal Plant Sciences 50; 705-709

Jham, G.N., B.R. Moser, S.N. Shah, R.A. Holser, O.D. Ghingra, S.F. Vaughn, M.A. Berhow, J.K. Winkler-Moser, T.A. Isbell, R.K. Holloway, E.L. Walter, R. Natalino, J.C. Anderson and
D.M. Stelly. 2009. Wild Brazilian Mustard (Brassica juncea L.) seed oil methyl esters as biodiesel fuel. Journal of the American Oil Chemistsé Society 86, 9, 917-926. doi.org/10.1007/s11746-009-1431-2.

Karaaslan, D. 1999. A research on determining the rapeseed varieties that can be grown under the conditions of Diyarbakır. 3rd National Field Crops Congress 15-18 November (1999), Adana, Volume II. Industrial Crops 328-333.

Kayacetin, F., F. Onemli, G. Y1lmaz, A. Kınay, H. Hatipoglu, M.N. Kivilcım, N. Kara, A. Kose and F. Sefaoglu. 2017. Effect of row spacing on yield, yield components and crude oil of autumn and spring sowed mustard (Sinapis arvensis L.) in eight locations of Turkey. Journal of Agricultural Sciences 24(4): 471-487. doi.org/10.15832/ankutbd.490966

Kayacetin, F., F. Onemli, G. Yılmaz, K.M. Khawar, A. Kınay, H. Hatipoglu, M.N. Kivilcim, N. Kara, A. Kose, F. Sefaoglu and K.A. Ozaydın. 2017. Growing degree day and seed sield relationships in Mustard (Brassica juncea L.) under different sowing seasons and locations of Turkey. Journal of Agricultural Sciences 25(3): 298-308 doi.org/ 10.15832/ankutbd.424218

Khan, H., M.A. Khan and M.S. Baloch. 2000. Effect of nitrogen and phosphorus on growth and yield of Brassica juncea $\mathrm{L}$. Directorate of Publication Pakistan Journal of Biological Sciences 3(8): 1231-1233.

Khan, FA, H. Javid, Z. Mohammad and S.M.M. Shah. 2011. Biodiesel production from mustard oil, coal ash using as catalyst. Middle East Journal of Scientific Research 8(5): 866872.

Keivanrad, S. and P. Zandi. 2012. Effect of nitrogen levels on growth, yield and oil quality of indian mustard grown under different plant densities. Thai Journal of Agricultural Science 45(2): 105-113. doi.org/10.2478/cerce-2014-0009

Keivanrad, S. and P. Zandi. 2014. Effect of nitrogen levels on growth, yield and oil quality of Indian mustard grown under different plant densities. Cercetări Agronomice în Moldova Vol. XLVII, No. 1 (157).

Kovács, A.B., I. Kincses, I. Vágó, J. Loch and T. Filep. 2009. Effect of application of nitrogen and different nitrogen-sulfur ratios on the quality and quantity of mustard seed. Communications in Soil Science and Plant Analysis 40(4): 453-461. doi.org/10.1080/00103620802694399.

Li, F., B. Chen, K. Xu, J. Wu, W. Song, I. Bancroft, A.L. Harper, M. Trick, S. Liu, G. Gao, N. Wang, G. Yan, J. Qiao, J. Li, H. Li, X. Xiao, T. Zhang and X. Wu. 2014. Genome-wide association study dissects the genetic architecture of seed weight and seed quality in rapeseed (Brassica napus L.). DNA Research 21(4): 355-367. doi.org/ 10.1093/dnares/dsu002

Mao, Shufang., Y. Han, X. Wu, T. An, J. Tang, J. Shen and Z. Li. 2012. Comparative genomic in situ hybridization (cGISH) analysis of the genomic relationship among Sinapis arvensis, Brassica rapa and Brassica nigra. Hereditas 149: 86-90.

Motlagh, S.M., A. Pirzad and B. Delkhosh. 2012. Effect of irrigation disruption and biological phosphorus on the biomass and seed yield of canola (Brassica napus L.). International Journal of Agriculture and Crop Sciences 4(1): 489-495

McKenzie, R.H., E. Bremer, L. Kryzanowski, A.B. Middleton, E.D. Solberg, G. Coy and J. Harapiak. 2003. Yield benefit of phosphorus fertilizer for wheat and canola in Alberta. Canadian Journal of Soil Science 83: 431-441. DOI.10.4141/S02-078

Metzger, J.O. and U. Bornscheuer 2006. Lipids as renewable resources: current state of chemical and biotechnological conversion and diversification. Applied Microbiology and Biotechnology 71: 13-22. 
Mir, M.R., M. Mobin, N.A. Khan, M.A. Bhat, N.A. Lone, K.A. Bhat, S.M. Razavi, S.A. Wani, N. Wani, S. Akhter, S. Rashid, N.H. Masoodi and W.A. Payne. 2010. Effect of fertilizers on yield characteristics of Mustard (Brassica juncea L.). Journal Physiopthol 2(10): 20-24.

Montemurro, F., D. De Giorgio, F. Fornaro, E. Scalcione and C. Vitti. 2007. Influence of climatic conditions on yields, $n$ uptake and efficiency in sunflower. Italian Journal of Agrometeorology 2: 28-34.

Mozaffari, S.N., B. Delkhosh and A.S. Rad. 2012. Effect of nitrogen and potassium levels on yield and some of the agronomical characteristics in Mustard (Brassica juncea L.) Indian Journal of Science and Technology 5(2): 2051-2054

Nabi, Md.N., Md.S. Akhter and M. Md. Shahadat. 2006. Improvement of engine emission withconventional diesel fuel and diesel-biodiesel blends. Bioresour Technology 97: 372378. doi.org/10.1016/j.biortech.2005.03.013

Panotra, N., A. Kumar and O.P. Singh. 2016. Impact of different levels of fertilizer on growth and yield of indian mustard (Brassica juncea coss) under irrigated condition of Western U.P. I.J.S.N. 7(4): 802-804.

Patel, R.H., V. Sharma and V.P. Usadadia. 2004. Influence of irrigation schedule, spacing and nitrogen on growth, yield and quality of mustard. Department of Agronomy, Gujarat Agricultural University. India 5(2/3): 290-293.

Reddy, B.N. and M.N. Sinha. 1989. Integrated fertilizer and water management to boost mustard production. Indian farming 39(5): 5-6.

Reager, M.L, S.K. Sharma and R.S. Yadav. 2006. Yield attributes, yield and nutrient uptake of Indian mustard (Brassica juncea L.) Influenced by nitrogen levels and its split application in arid western Rajasthan. Indian Journal Agronomy 51(3): 213216.

Roche, J., A. Essahat, M. Bouniols, Z. El-Asri, M. Mouloungui, M. Mondies and M. Alghoum. 2004. Diversified composition of sunflower (Helianthus annuus L.) seeds within cultural pratices and genotypes (hibrit and populations). HELIA. 27 (40): 73-98 doi.org/.10.2298/hel0440073r

Rodriguez, D., F.H. Andrade and J. Goudriaan. 2000. Does assimilate supply limit leaf expansion in wheat grown in the field under low phosphorus availability. Field Crops Research 67: 227-238. doi.org/10.1016/S0378-4290(00)00098-8

Said-AL Ahl, H. A. H., H.M. Mehanna and M.F. Ramadan, 2016. Impact of water regime and phosphorus fertilization and their interaction on the characteristics of rapeseed (Brassica napus L:) and fatty acid profile of extracted oil. Communications in Biometry and Crop Science 11(1): 64-76.

Singh, S.B and O.V.S. Thenua. 2016. Effects of phos pho rus and sul phur fertilization on yield and nps uptake by mustard (Brassica juncea L.) Progressive Research - An International Journal Society for Scientific Development 11(1): 80-83.

Shafi, M., S. Khan and M. Nazir. 1992. Yield and yield components of wheat in relation to different phosphorus and radiation levels Sarhad. J. Agri. 8: 1-5.

Solanki, R.L., S. Mahendra, S.K. Sharma, H.S. Purohit and V. Arvind. 2015. Effect of different level of phosphorus, sulphur and PSB on the yield of Indian mustard (Brassica juncea L.) and soil properties and available macronutrients. Scholarly Journal of Agricultural Science 5(9): 305-310.

Steel, R.G.D. and J.H. Torrie. 1980. Principles and procedures of statistics. McGaw-Hill Book Company. Inc. N.Y.

Shorna, S.I., M.A.S. Polash, M.A. Sakil, M.A. Mou, M.A Hakim, A. Biswas and M.A. Hossain. 2020 Effects of nitrogenous fertilizer on growth and yield of Mustard Green. Tropical Plant Research 7(1): 30-36 doi.org/10.22271/tpr.2020.v7.i1.005

Tahir, M., M.A. Malik, A. Tanveer and R. Ahmad. 2003. Effect of npk levels on seed yield and oil contents of canola. Pakistan Journal of Life Social Sciences 1(2): 127-132.

Tuncturk, M. 2008. Effects of Various Phosphorus Fertilizer on the Yield and Yield Parameters of Some Summer Rape (Brassica napus ssp. oleifera L.) Cultivars. Ankara University Journal of Agricultural Sciences 14 (3): 259-266.

Vicianová, M., L. Ducsay, P. Ryant, M. Provazník, A. Zapletalová and M. Slepčan. 2020. O1lseed rape (Brassica napus 1.) nutrition by nitrogen and phosphorus and its effect on yield of seed, oil and higher fatty acids content. Acta Unıversitatis Agriculturae ET S1lviculturae Mendelianae Brunensis 68(1): 129-136.

Wang, N., L. Shi, F. Tian, H. Ning, X. Wu, Y. Long and J. Meng 2010. Assessment of FAE1 polymorphisms in three Brassica species using EcoTILLING and their association with differences in seed erucic acid Contents. BMC Plant Biology 10:137-139

Weiss, E.A. 1983. Safflower: In: Oilseed Crops, Tropical AgricultureSeries, Longman Inc., Leonord Hill Books, New York, USA. 